LSP International Journal, Vol. 7, Issue 1, 2020, 99-119

(C) Universiti Teknologi Malaysia

E-ISSN 2601-002X

DOI: https://doi.org/10.11113/lspi.v7n1.100

\title{
Teachers' Practices and Perceptions of the Use of ICT in ELT Classrooms in the Pre- Covid 19 Pandemic Era and Suggestions for the 'New Normal'
}

\author{
Ang Sher Ryn \\ Faculty of Education, Universiti Teknologi Malaysia, 81310 UTM Johor Bahru, Johor, Malaysia \\ Sandaran, SC \\ Language Academy, Universiti Teknologi Malaysia, 81310 UTM Johor Bahru, Johor, Malaysia \\ Submitted: 10/01/2020. Revised edition: 25/06/2019. Accepted: 28/06/2020. Published online: 30/06/2020
}

\begin{abstract}
ICT is the acronym for Information and Communication Technology and refers to a varied set of technological tools and resources used communication to create, disseminate, store, and manage information. In the context of teaching and learning, the integration of ICT can assist students in acquiring English language competency as well as enhancing the quality of their learning experience. Previous research has shown that there exists barriers to implementing ICT in teaching and learning, i.e. teacher-level barriers and school-level barriers. Despite there being barriers for ICT integration in teaching and learning, the Covid 19 pandemic has fast tracked ICT integration, and today teachers and students worldwide have been forced to work online regardess of whether they are prepared in terms of knowledge, skills and resources for the 'technologisation' of teaching and learning. This study investigated teachers' practices and perceptions in using ICT in English Language Teaching (ELT) with a focus on the obstacles faced by English language teachers in using ICT in their lessons, measures taken to increase their ICT usage and the perceptions of using ICT in the classroom. Respondents in this study were 18 teachers in a premier school with either a training in English language teaching or English background and at least 5 years' teaching experience. Using a 60item questionnaire, data was gathered on respondent's ICT literacy, obstacles faced, ICT usage and their perceptions of using ICT in the classroom. The findings of the research suggest the lack of ICT literacy and time allocated for teaching and learning process as the main obstacles faced by English teachers in using ICT. In addition, the overall ICT literacy of the teachers were still limited and needed to be improved especially in the use of internet so that they would gain more confidence in implementing ICT in their classroom. While the findings show that the main problems that had restricted the teachers in using ICT in their teaching is the lack of ICT skills and confidence in implementing ICT in the classroom, this study recommends that schools provide more training and ICT courses to teachers to improve teachers' ICT literacy as a measure to embrace the new normal of the Covid 19 pandemic digitalised era.
\end{abstract}

Keywords: ELT, ICT literacy, teachers perceptions, digital, Covid 19

\subsection{INTRODUCTION}

ICT is the acronym for Information and Communication Technology and refers to a 'diverse set of technological tools and resources used to communicate, and to create, disseminate, store, and

*Correspondence to: Sandaran, SC (email: shanti@utm.my) 
manage information' (Blurton, 1999; Albirini, 2006; Simin and Mohammad Sani, 2015). These technologies take into account the internet, computers, broadcasting technologies such as radio, television and telephone. However, because of the development of technology and demand, the internet and computer have gained more attention to be used as instructional tools in education compared to others. With ICT, web-based learning in second language teaching and learning has come to the fore especially in English language as web-based learning provides the learners with a variety of hyperlinked multimedia documents and variety of tools or programs that can support language teachers to integrate a variety of resources into the language classroom (Albirini, 2006). The multimedia elements such as images, texts, audio, video, animation and interactivity are now a part of the delivery of authentic materials and interactive presentations in the language classroom (Shetzer and Warschauer, 2000). Indeed, ICT in the form of digital literacy becomes one of the skills that students must acquire besides words and numerical literacy in the 21 st era of learning. As such, teachers as the front-liners in education need to master digital literacy by having the ability of using ICT to find, create, and communicate (Hafifah, 2020). In the era of Covid 19 pandemic, ICT integration is part of the 'new normal', as teaching and learning has gone online, thus, it is necessary for more research on teachers practices and perceptions of ICT use in the language learning classroom, which the current study investigates.

In education, the use of ICT was introduced as a means to help teachers and students in the process of teaching and learning. Through the use of Internet and Intranet, students could surf for any information they need, and this is very important to broaden their mind set. For the teachers, they can search for a range of teaching materials to suit their students' needs as the Internet allows them to download any information that they may need. They can also share their ideas with others by uploading it to the website. Both teachers and students can even create and publish their own resources online for others to use as part of the learning process besides contributing ideas and expertise in creating more quality resources that could benefit both the user and the publisher. In fact, a review of literature on technology use in English language learning indicated that the effective use of new technologies improves learners' language learning skills (Ahmadi, 2018).

The use of ICT in teaching and learning has long been established in the Malaysian education system for the teaching and learning process. ICT is one of the main elements in the recent Malaysian Education Blueprint (2013-2025) as it is seen as the future of education (Simin and Mohammad Sani, 2015). The Malaysian Education Blueprint 2013-2015 has stressed the importance of ICT to be a part of all levels of learning, i.e. that internet usage and virtual learning must be implemented for selfguided learning of students. Such an emphasis is primarily because the Malaysian government recognises the many benefits of the use of ICT in education. According to Chan (2002), the Malaysian government has provided a comprehensive guideline for the use of ICT in the education system and this included the Malaysian Smart School Project launched in 1997. This project was aimed at changing the culture of the previous educational system with memory-based learning to a better learning environment. SMART Schools have proven to improve student performance. Through ICT, these schools use ICT to improve and transform the education system to fulfil today's technological needs and to prepare the country with a technological literate work force equipped with critical thinking skills to participate fully in the global economy of the 21 st century. SMART schools also 
provide emphasis on developing a well-balanced individual in every aspect - intellectual, spiritual, emotional and physical well-being. The students in the SMART Schools program go through various activities involving ICT where they were involved actively in collaborative and evaluative learning in the English language lessons as the lessons were helpful in improving their creative and critical thinking skills (Ya'acob et al., 2005).

The government has also tried to enhance the use of internet by setting up a website called MySchoolNet to help teachers and students in accessing the readily available educational information by providing them with related links in the website. Besides that, the Electronic Book Project was carried out in 2001 and has shown that the device did improve the computer literacy of the students besides engaging them in learning. E-learning and some computerised programmes were also practiced in schools so that the students would be able to cope with the fast-growing technology. Thus, ICT in ELT should be practiced in every school especially those which have been already equipped with ICT facilities. And in embracing the 'new normal', ICT intergration has become an integral feature.

The Malaysian government has invested in providing schools with the basic equipment, but many schools especially rural schools still prefer to use traditional teaching methods. The teachers were also trained to use the facilities provided and were supplied with CD-Roms as teaching aid according to the subjects they taught. However, despite the measures taken by the Malaysian government to help schools integrate ICT, research show that there appears to be a lack of initiatives taken by teachers to implement ICT in their lessons. Masood and Ngah (2003) found that the teachers did not have any problems accessing and utilising the computers but unfortunately the computers were being used as a glorified typewriter for record keeping and word processing purposes rather than used in the class as a teaching tool. Similarly, Azizah (2006) stated that the use of ICT such as the course materials had failed to gain the interest of the teachers as the course materials available did not match the teaching and learning process and thus the teachers preferred to use the traditional methods. Thus, this study is timely as it investigates teachers' practices and perceptions of using ICT in English Language Teaching (ELT). It addresses the following research questions:

1. What are the obstacles faced by the English language teachers in using ICT in their lessons?

2. What are some of the ways that could increase teachers' use of ICT in the classroom?

3. What are the perceptions of the teachers about teaching using ICT and without ICT in the classroom?

The findings will reveal the obstacles faced by English language teachers when using ICT in their ELT classrooms that may contribute to the lack of ICT usage in class. This finding will provide helpful information to schools and the education department in their efforts to improve the use of ICT in teaching and learning as part of the 'new normal' Covid 19 era.

\section{LITERATURE REVIEW}

The current study investigates teachers' perceptions and use of ICT in language classrooms. The discussion in this section will report on relevant literature on the use of ICT in the classrooms, the 
benefits of ICT and barriers, among other aspects. The multitude of benefits of ICT in language learning and teaching has become the focus of researchers in recent years. ICT can help students acquire the target language which acts as a medium and in this way students will acquire English language slowly without them realizing it. Singhal (2010) states that language acquisition is a longterm process which is affected by the surrounding environment and the type of device that a learner uses. Singhal adds that the second language learning device (in terms of computer and internet) is a powerful device that is very useful in practicing the four skills, i.e. listening, writing, speaking and reading. Becker (2000) also states that ICT activities provided by the teachers offer more opportunities for active, independent learning that can increase student motivation to learn. This is because ICT will provide students with more student-centred activities where the students need to explore and discover the learning input themselves rather than depend solely on the teacher's input (Simin and Mohammad Sani, 2015).

In a similar vein, Sivapalan and Ahmad (2010) found that the use of ICT for literature learning had increased learner understanding. The lessons were more enjoyable and alive in comparison to the traditional approach as learners involved themselves more in the learning and were more responsible for their own learning as well. When they involved themselves in learning, their skills and performance in the English language improved. Marcheggiano (2000), who had looked at primary schools in Italy on the performance of students with the use of ICT, showed that the students had improved in terms of performance and communication skills with the use of ICT. The students also preferred their teachers to integrate ICT in their lessons.

According to White (2009), the use of internet in schools has made the sharing of information in social network possible where the students are able to interact with each other and share their ideas and thought. Information and data are always transmitted in two forms, which are the synchronized form (i.e. Facebook, Friendster, Twitter, Blogging, and e-learning) and the asynchronize form (i.e. time is needed for the sharing of information to take place and this includes the use of Yahoo mail, Hotmail). By creating a discussion group on Facebook and providing students with weekly questions to answer, a high level of motivation and grammatical complexity above what is normally observed can be achieved. The discussion group has shown some very positive improvements in grammar and spelling as well as grammatical complexity. Students became involved in their own learning and began to use English for informal communication (White, 2009).

Students would be more motivated in learning when the teachers implement ICT in the classroom. Students engage themselves in learning activities because of intrinsic motivation or extrinsic motivation (O'Donnell et al., 2007). Intrinsic motivation is the inherent propensity to engage one's interests and to develop one's capacities (Deci and Rayne, 1985). In order to enhance students' motivation, teachers need to find ways to involve students and nurture their needs. Teachers are able to do this by having interesting, fun and enjoyable activities in class as this will increase the students' spontaneous satisfaction and they will continue to engage with the learning (Deci and Ryan, 1985). Similarly, Amabile and Hennessey (1992) also elaborated on the positive effect of intrinsic motivation. They stated that people would be most creative when they felt motivated primarily by the interest, enjoyment, satisfaction, and challenge of the work itself - rather than by external pressure. This 
means that students should not be forced to learn the language, but teachers should organise more motivating activities to motivate the students to learn (Amabile and Hennessey, 1992. P:55).

Ibrahim (2010) further confirms the multitude of benefits of ICT in English Language Teaching. ICT brings significant and positive impact to the students such as students can learn at their own pace with the availability of the materials in web, computer-based, or CDs; their attitude toward learning change and will be more motivated to learn; learners can focus on important part of their learning and they can learn according to their own pace; learning will be done in a more authentic environment using more authentic materials; while for the teachers ICT helps them prepare materials that are relevant to the needs of the students (Ibrahim, 2009). As 95\% of the websites use English language as the medium of communication. The students will slowly acquire the language indirectly when they use English language as their medium for instructions and this happens when the students are required to read the instructions or activities shown (Hanapiah, 2002). According to Blood (2002), blogs, weblog or online journals are new platforms for individuals to express and share ideas and thoughts with the public and has become a popular trend for internet users. Most of the users will make use of the environment for self-expression and self-empowerment and this practice has made people become more thoughtful and more critical in their writing. Thus, optimum learning becomes proportional to the learners' activity level.

Despite the many benefits of using ICT in the classroom, research shows that there are barriers to the successful implementation of ICT in schools. Bingimlas (2008) showed that the barriers of implementing ICT in teaching and learning are divided into, namely, teacher-level and school-level barriers. Teacher-level barriers include problems such as lack of confidence in using ICT, lack of competence, and resistance to change and negative attitudes toward the use of ICT are found. While for the school-level barrier, problems such as lack of time, lack of effective training, lack of accessibility and lack of technical support are said to affect the usage of ICT in schools. Preston et al., (2000) and Fabry and Higgs (1997) also agree that the lack of time would create a barrier for the teachers to explore and prepare ICT resources for their lesson thus unable to make full use of the ICT and integrate it into their lessons. According to Ibrahim (2004), the lack of equipment and connectivity in schools especially in rural areas has been one of the biggest challenges faced by Malaysian schools. However, according to Mahdum, Hadriana and Safriyanti (2019), it is essential to examine all these barriers as it is important in improving the readiness of teachers especially in rural areas regarding ICT use in the teaching and learning activities. Thus, this study expands upon previous studies, and investigated the use of ICT in the English Language classrooms in Malaysian schools. It focused more specifically on the perceptions of teachers based on their practice of using ICT for teaching and learning.

\section{RESEARCH METHOD}

The study used a quantitative approach for data collection and analysis which involved a selected school and 18 English language teachers as the respondents. The school was selected because it is ICT equipped - two computer labs with 42 computers, 2 sets of speakers, 2 sets of projectors, wireless 
internet access, and laptop for each teacher. Besides that, this school has a 'green board' which was used as an interactive blackboard and screen, and power supply for each of the classrooms. Apart from that, some students were provided with free laptops for self-learning. This shows that this Premier school already has all the equipment needed for ICT to be practiced in the ELT classroom. As this school has all the necessary resources for ICT integration in the ELT classrooms, it makes an ideal setting for the current study.

The data was collected through questionnaires. The questionnaire included some of the items adopted and adapted from the following studies:

i. Research instrument used by Mee and Zaitun (2006) in the study of 'Obstacles Toward the Use of ICT Tools in Teaching and Learning of Information Systems in Malaysian Universities'

ii. Chia and Lau (2008) in the study of 'Teachers' perceptions of the use of ICT as an instructional tool in Mathematics and Science'

iii. Survey on 'Students' Perceptions of the Use of ICT in University Learning and Teaching by a European wide SPOT+ team' (2001).

The questionnaire consists of 5 Sections with 60 questions overall and divided into five sections, namely sections A, B, C, D and E. Section A is the profile of the respondents where there are five items in this section. Section B is on the ICT literacy of the respondents with 17 items. While section $\mathrm{C}$ is to determine the obstacles faced in using the ICT in teaching with 15 items. As for items in section $\mathrm{D}$, to determine the types of ways that could increase teachers' usage in ICT in their classroom with 5 open ended questions. Section E was to find out the teachers' perceptions in using ICT in their classroom with 18 questions. The questionnaires were piloted to a group of 10 respondents to assess its validity before they were distributed to the English language teachers.

Before the actual data collection period and before the questionnaires were distributed, a pilot study was conducted to assess the validity of the research instrument, i.e. the questionnaires and the interview questions. A total of 10 teachers were involved in the pilot study. Following this, the questionnaires were distributed to all 18 English Language teachers in the school. The data was analysed using the SPSS software and the results were presented through the percentage for each question answered.

\section{RESULTS AND DISCUSSION}

The study set out to investigate the perceptions of teachers and their practice of using ICT in the ELT classroom. This section presents the findings and discussion. 


\section{Background of the Teachers, ICT Literacy and Usage}

13 out of 18 of the respondents of this study were very experienced teachers with 16 years or more teaching experience, two teachers with 6-10 years of teaching experience, 1 with 15 years and another 2, with 1-5 years of teaching experience. Most of the respondents have a Bachelor in Education (TESL) qualification, followed by 5 respondents with a Diploma in Education. 1 of the respondents is an English Major Degree holder while the other 2 respondents (11.1\%) are graduates with a BA in History and English Literature. The majority of the teachers have taught for more than 5 years. Besides that, most of the English Language teachers are also graduates who specialised in ELT. With their teaching experience and specialised skills in ELT, it can be said that the teachers know the needs of the students and the most appropriate teaching methodologies for their students.

Most of the teachers stated owning a computer and having internet connection. This shows that the teachers are exposed to ICT and that they already have at least the basic knowledge on the functions of the computer and its programmes. With the ICT skills and their experience in teaching, they should be able to implement ICT in their ELT classrooms according to the needs of the students. In general, we could say that these English Language teachers belong in the 'average' ICT literacy skills level. They are most skilled in the use of the word processor. This correlates with the findings by Jegede et al. (2007) and Cuckle et al. (2000) most teachers were more skilled in word processing compared to other applications.

Padurean and Margan (2009) stated that in general, teachers still needed some training and practice to improve their ICT skills, although they were already familiar with the major functions of the programmes and ICT equipments. The teachers need more training to improve their skills of email programmes, presentation manager, database and spreadsheet. The teachers should also be exposed with the use of authoring programmes to create their own webpages as they are the ones who know the students' needs. They should be able to master all the basic ICT programmes as these programmes could help in reducing their work load and at the same time produce more suitable teaching and learning materials for the students. Research by Sa'ari et al. (2005) and Jegede et al. (2007) concluded that teachers who were more competent in the use of computers had more favourable attitudes toward ICT use in the classroom. The current study shows that, teachers should be trained to increase their ICT literacy so that they would have a more positive attitude towards ICT and could apply what they have learnt to their lessons in the classroom.

More than half of the respondents $(66.7 \%)$ spent their time on the internet searching for ideas for teaching while other respondents $(50.0 \%)$ stated they searched for teaching materials such as poems, worksheets, language exercises, samples of essays and articles. $33.3 \%$ of the respondents were interested in searching for language games. Songs and lyrics, videos and web dictionary were the least popular items with the teachers as they rarely looked for these, only $5.6 \%$ of the respondents searched for these types of materials from the internet. Overall, the most popular online resources for the teachers were materials on ideas for teaching.

Table 1.0 shows the teachers' usage of ICT in the EL classroom. The majority of the teachers did not (Never) use ICT in the ELT classroom. Videoconferencing was the least used activity compared to the other application. This is followed by using website with interactive features such as assessment tasks, online tasks or learning materials and academic support and advice via email 
between teachers. More than half of the respondents had never used websites with interactive features in their lessons, while the rest have never applied academic support and advice via email between teachers to students in the classroom.

Table 1.0 ICT usage in the EL classroom

\begin{tabular}{|c|c|c|c|c|c|}
\hline No. & Items & $\begin{array}{l}\text { Several } \\
\text { Items }\end{array}$ & Once & Never & $\begin{array}{l}\text { Never } \\
\text { Heard of } \\
\text { This }\end{array}$ \\
\hline 1. & $\begin{array}{l}\text { A course with a website } \\
\text { with interactive features } \\
\text { such as, assessment, online } \\
\text { tasks or learning materials }\end{array}$ & $16.7 \%$ & $22.2 \%$ & $61.1 \%$ & $0.0 \%$ \\
\hline 2. & Online discussion forum & $11.1 \%$ & $0.0 \%$ & $88.9 \%$ & $0.0 \%$ \\
\hline 3. & Video-conferencing & $5.6 \%$ & $0.0 \%$ & $94.4 \%$ & $0.0 \%$ \\
\hline 4. & $\begin{array}{l}\text { Academic support and } \\
\text { advice via email (teachers } \\
\text { to teachers) }\end{array}$ & $22.2 \%$ & $22.2 \%$ & $55.6 \%$ & $0.0 \%$ \\
\hline 5. & $\begin{array}{l}\text { Academic support and } \\
\text { advice via email (teachers } \\
\text { to students) }\end{array}$ & $5.6 \%$ & $5.6 \%$ & $88.9 \%$ & $0.0 \%$ \\
\hline
\end{tabular}

As for the most preferred application among the teachers, academic support and advice via email among teachers were the top choice compared to the rest. This is followed by using website with interactive features in the classroom. The respondents do include online discussions in class. Videoconferencing was the least option. The category of knowing the application (Never heard of this), all of the respondents stated that they had heard of all the applications before and they knew about the function and the benefits of using it in the classroom. Therefore, it can be said that the teachers spend less time on searching for internet resources as most of the time, they depend on the prescribed resources such as textbooks or reference books as their teaching materials.

In general, no proper actions have been taken by the teachers to improve their teaching strategies to provide a better learning environment for the students via ICT usage. From the data gathered above on the usage of all the applications by the teachers, the school did have the facilities to carry out all the tasks listed above as some of the teachers had make an effort to use these facilities several times. But the majority of the English language teachers had never attempted to apply the tasks in their lessons although all of them had heard of these helpful applications. Therefore, it could be said that the teachers there did not practice ICT usage in their classrooms although they were provided with the facilities needed. Furthermore, the findings show that they only use ICT as a tool to search for some new ideas in teaching so that they could adapt the new ideas of teaching in their classrooms according to what they thought as appropriate for both the teachers and also students. 
On the other hand, some teachers had attempted to use the applications such as online discussion forum but because of lack of a proper site for the teachers and students to actually have their discussion forums, most of the teachers did not choose to have this task with the students. Although the school has its own website and e-learning site, the website was not updated regularly and this has made the usage of online discussion forum a more challenging task to do. Academic support and advice via email among teachers and students were not the option for the school. This was because this school is situated in a rural district where not every student in this school owns a personal computer and internet connection at home. Although the government had sponsored and given some privileges such as laptops to some of the needed students but without the internet connection, they could not complete the task of academic support and advice via email with the teachers. Therefore, the teachers could be more careful about the selection of the activities that involved ICT usage and all the activities could be carried out and completed in the school where all the students would be provided with the facilities.

Only a few teachers use the software provided in the KBSM syllabus during their lessons. Most of the teachers preferred not to use any software in their classrooms because of time constraints. Most of the respondents also stated that time constraints had affected their choice in using ICT in the classroom as they had to take time to set up the systems. They stated that they had to rush and finish the lessons on time based on the KBSM syllabus and they did not have extra time to waste in setting up the system that was not their expert field. The problem of time constraint could be solved if the teachers could prepare everything well before the lesson, it would then not be a problem at all and the lesson would be more fun with the implementation of ICT tools in the classroom.

Besides that, many of the teachers also stated that they were not provided with any software in the KBSM syllabus so they did not practice ICT in their teaching and learning activities. However, the teachers did not take any initiatives to find other software that is equivalent to the KBSM syllabus in the market to replace the software / programmes. The reason for software not being provided by the government could actually be solved if the teachers could spend some time and effort looking for other replacement software for the students.

Moreover, limited ICT room was rated to be one of the problems that inhibit the use of ICT in the classroom as the teachers need to book the room earlier before the class starts to make sure that the ICT room was not occupied by others. In this case, the teachers could cooperate and divide the classrooms according to the needs and make sure that every class would have at least two periods or two lessons in a week in the ICT lab. This would ensure that the teacher could apply the use of ICT in the lessons. Moreover, the teachers could also bring their own ICT tools such as laptop, speaker and LCD projector to the classroom as most of the teachers were sponsored with a free laptop and LCD projector to help in their teaching. The teachers could use of all the facilities provided and equip themselves with a higher ICT literacy so that they could at least know the basic functions of the programmes or software they would be using.

\section{Obstacles Faced in Using ICT in the Classroom}

The top five reasons affecting the teachers" usage of ICT (listed inTable 2.0) in the classroom are "I have to put in extra effort when integrating ICT tools in my teaching", followed by "I do not have 
extra time to set up the ICT tools for my teaching," "ICT tools are changing too fast to be up-todate," "the software available is not sufficient to accommodate ICT supported teaching" and "certain software is difficult to learn and use."

Table 2.0 Obstacles faced in using ICT in the classroom

\begin{tabular}{|c|c|c|c|c|c|c|}
\hline No & Items & $\begin{array}{l}\text { Strongly } \\
\text { Agree }\end{array}$ & Agree & $\begin{array}{l}\text { Not } \\
\text { Sure }\end{array}$ & Disagree & $\begin{array}{l}\text { Strongly } \\
\text { Disagree }\end{array}$ \\
\hline 1. & $\begin{array}{l}\text { I have to put in } \\
\text { extra effort when } \\
\text { integrating ICT } \\
\text { tools in my } \\
\text { teaching }\end{array}$ & $27.8 \%$ & $72.2 \%$ & $0.0 \%$ & $0.0 \%$ & $0.0 \%$ \\
\hline 2. & $\begin{array}{l}\text { I do not have } \\
\text { extra time to set } \\
\text { up the ICT tools } \\
\text { for my teaching }\end{array}$ & $33.3 \%$ & $44.4 \%$ & $5.6 \%$ & $16.7 \%$ & $0.0 \%$ \\
\hline 3. & $\begin{array}{l}\text { I have problems } \\
\text { getting quality } \\
\text { training program }\end{array}$ & $16.7 \%$ & $33.3 \%$ & $11.1 \%$ & $38.9 \%$ & $0.0 \%$ \\
\hline 4. & $\begin{array}{l}\text { I have difficulties } \\
\text { getting support } \\
\text { from technical } \\
\text { staff }\end{array}$ & $5.6 \%$ & $33.3 \%$ & $16.7 \%$ & $44.4 \%$ & $0.0 \%$ \\
\hline 5 . & $\begin{array}{l}\text { The hardware } \\
\text { available is not } \\
\text { sufficient to } \\
\text { accommodate } \\
\text { ICT supported } \\
\text { teaching }\end{array}$ & $5.6 \%$ & $44.4 \%$ & $33.3 \%$ & $16.7 \%$ & $0.0 \%$ \\
\hline 6. & $\begin{array}{l}\text { The software } \\
\text { available is not } \\
\text { sufficient to } \\
\text { accommodate } \\
\text { ICT supported } \\
\text { teaching }\end{array}$ & $0.0 \%$ & $61.1 \%$ & $11.1 \%$ & $27.8 \%$ & $0.0 \%$ \\
\hline 7. & $\begin{array}{l}\text { Certain software } \\
\text { is difficult to } \\
\text { learn and use }\end{array}$ & $0.0 \%$ & $55.6 \%$ & $27.8 \%$ & $16.7 \%$ & $0.0 \%$ \\
\hline 8. & $\begin{array}{l}\text { ICT tools are } \\
\text { changing too fast } \\
\text { to be up-to-date }\end{array}$ & $11.1 \%$ & $61.1 \%$ & $16.7 \%$ & $11.1 \%$ & $0.0 \%$ \\
\hline 9. & $\begin{array}{l}\text { The network } \\
\text { connectivity is } \\
\text { poor }\end{array}$ & $5.6 \%$ & $44.4 \%$ & $11.1 \%$ & $16.7 \%$ & $22.2 \%$ \\
\hline
\end{tabular}




\begin{tabular}{|c|c|c|c|c|c|c|}
\hline No & Items & $\begin{array}{l}\text { Strongly } \\
\text { Agree }\end{array}$ & Agree & $\begin{array}{l}\text { Not } \\
\text { Sure }\end{array}$ & Disagree & $\begin{array}{l}\text { Strongly } \\
\text { Disagree }\end{array}$ \\
\hline 10. & $\begin{array}{l}\text { The hardware } \\
\text { available is } \\
\text { already outdated } \\
\text { to accommodate } \\
\text { ICT supported } \\
\text { teaching }\end{array}$ & $5.6 \%$ & $27.8 \%$ & $27.8 \%$ & $38.9 \%$ & $0.0 \%$ \\
\hline 11. & $\begin{array}{l}\text { The software } \\
\text { available is } \\
\text { already outdated } \\
\text { to accommodate } \\
\text { ICT supported } \\
\text { teaching }\end{array}$ & $0.0 \%$ & $16.7 \%$ & & $33.3 \%$ & $5.6 \%$ \\
\hline 12. & $\begin{array}{l}\text { Students lack ICT } \\
\text { skills }\end{array}$ & $0.0 \%$ & $33.3 \%$ & & $44.4 \%$ & $0.0 \%$ \\
\hline 13. & $\begin{array}{l}\text { Students give } \\
\text { negative feedback } \\
\text { on ICT supported } \\
\text { teaching }\end{array}$ & $0.0 \%$ & $16.7 \%$ & & $55.6 \%$ & $0.0 \%$ \\
\hline 14. & $\begin{array}{l}\text { I find it difficult } \\
\text { to change from } \\
\text { my current } \\
\text { teaching practice } \\
\text { to integrate ICT } \\
\text { tools in teaching }\end{array}$ & $11.1 \%$ & $27.8 \%$ & & $50.0 \%$ & $0.0 \%$ \\
\hline 15. & $\begin{array}{l}\text { I lack confidence } \\
\text { in integrating } \\
\text { ICT tools in my } \\
\text { teaching }\end{array}$ & $16.7 \%$ & $27.8 \%$ & & $50.0 \%$ & $0.0 \%$ \\
\hline
\end{tabular}

From the items on "I have to put in extra effort when integrating ICT tools in my teaching," "ICT tools are changing too fast to be up-to-date," "the software available is not sufficient to accommodate ICT supported teaching" and "certain software is difficult to learn and use," we can conclude that they are not willing to put in any extra effort to explore and search for the new features that could actually help in their teaching. These reasons seem to be in line with Bingimlas' (2008) views that the problems of lack of confidence in using ICT, lack of competence, and resistance to change and negative attitudes toward the use of ICT would cause the teachers to avoid using ICT in the classroom.

Besides that, the item "I do not have extra time to set up the ICT tools for my teaching" suggested that the lack of time was one of the biggest barriers for the teachers to practice ICT in their lesson. Most of the teachers complained that they had only 5 periods of English lessons per week and the time given was not enough for them to complete all their lessons according to the KBSM syllabus. 
They did not want to waste time on setting up the equipments every time they wanted to use ICT in the lesson and therefore they would try to avoid the implementation of ICT in their classroom. This is similar to the views of Bingimlas (2008), Preston et al. (2000) and Fabry and Higgs (1997) that the lack of time would create a barrier for the teachers to explore and prepare ICT resources for their lesson, thus they would not want to make full use of the ICT and integrate it into their lessons.

The results show that among the problems faced, the top reasons that caused teachers to avoid integrating ICT usage in the classroom are the lack of ICT literacy in the teachers themselves and the reluctance to change from their comfort zone. With their ICT literacy being limited, every task that involves ICT would be considered as difficult for them. Some of the teachers might also avoid involving themselves in using ICT in the classroom when as they prefer to stay in their comfort zone by using traditional teaching method of chalk and talk that they had mastered and used for ages.

\section{Types of Measures that Could Increase the Use of ICT in the Classroom}

In terms of measures that could improve or encourage ICT usage in the classrooms, the teachers generally lack training. Only five of the respondents had received training on using ICT in teaching while the majority had never attended any ICT training before. From the respondents who had attended the training courses, it was found that most of the courses were on preparing teaching materials using Microsoft Words, Microsoft Excel, PowerPoint and some basic knowledge on how to manage the laptop or computer. This shows that the school did not provide much training programmes for the teachers, in particular programmes that could improve the teachers' ICT literacy. The majority of respondents who had attended ICT courses agreed that the training benefited them in terms of using the ICT tools. But the rest of the respondents did not agree with the benefits of the training programmes they had attended. This is because the trainings that they had attended were basic ICT programmes such as Microsoft Words, Microsoft Excel, and PowerPoint that they already know. We suggest that the schools should divide the teachers according to the level of proficiency in ICT and provide them with appropriate training based on their needs. The teachers would benefit a lot if they attend the appropriate training on ICT usage.

The majority of the respondents stated requiring better classrooms with well-equipped ICT facilities like laptops, LCD, internet access and local area networks. Apart from that, more than half of the respondents would like the authorities to provide more teaching materials such as CDs, PowerPoint slides to replace textbooks and handouts. Almost half of the respondents said that it would be good to organise more courses and seminars to expose them to current developments in the ICT field, while others said they would like to have more wireless Internet access in school.

From the findings it can be said that the teachers want the school to have more classrooms with well-equipped ICT facilities although the school already has some classrooms that are equipped with full ICT equipment. This is because of the growing number of students and the need for ICT is increasing for every subject. They might face problems of having not enough ICT classrooms if the number of students is growing while the classrooms still remain the same. Besides that, the teachers also want more teaching materials such as CDs to replace textbooks and handouts. This is because the 
students nowadays are more interested in learning through a variety of teaching materials rather than textbooks and handouts.

Moreover, the teachers also stated that they want more courses and seminars as this could help them to be up to date with the latest news and technologies so that they could apply them in their classrooms. With the latest news in hand, they would not miss out the latest practice in teaching so that both the teachers and the students would not feel left out. Lastly, the teachers stated needing more wireless Internet access at their school so that both the teachers and the students could access the internet anytime they needed it. Although the school has already provided internet connection at certain areas of the school, it would be better if the school could provide a full wireless service around the school so that the teachers and the students would not have problems in accessing the internet.

Most of the respondents stated that if the classes were fully equipped with ICT tools, they would like to start their introduction of the lesson by using the technology, e.g. showing students videos on short stories being taught, asking students to find out more information on the short story from the internet, play a song and relate it to the short story or play games that are related to the short story. This shows that the teachers are able to implement ICT in the classroom in their own creative ways. They are able to carry out activities based on the lessons with or without the implementation of ICT. If the school were to be provided with more facilities and the teachers were to equip themselves with more ICT skills, they would then surely apply ICT in their lessons as they do realise the importance of implementing ICT in the classroom. The Ibrahim (2010) has stressed on the importance of implementing ICT in the classroom and positive impacts of ICT in English Language Teaching especially for second language learners.

Majority of the teachers showed a positive attitude towards the use of ICT in ELT as they agreed that ICT usage would benefit the students and make the learning process more effective. The teachers said that the use of ICT tools in the classroom could make the process of learning fun and motivating as students could stay focussed longer. The is similar to findings by Marcheggiano (2000) and Singhal (2010) that ICT could provide students with more fun and joyful activities and improve students' performance and communication skills if it was integrated effectively in the classroom. Besides that, the teachers also stated that ICT tools could expose students to a wider range of knowledge instead of the limited knowledge from the textbook and agreed that ICT tools could present the information more clearly as the information could appeal to the students' sense of sight, hearing, feeling and thought that could make the students remember better and more motivated in learning. Amabile (1992), Deci and Ryan (1985) and Lee (2000) also found that the use of ICT in the classroom would increase motivation in students especially when the teachers offer a wide range of activities as this would make the students feel more independent with the use of ICT where they need to explore and discover the information themselves. In a similar vein, Lee (2000) explained that students would not just become the receivers of knowledge but the creators who could find their own way to the knowledge.

On the other hand, around 5 of the respondents were not sure about the effectiveness of the use of ICT tools in the classroom. They mentioned that some of the software provided were too difficult for the students with lower intermediate language skill and they said the process of learning would depend on the students' attitude of learning. The software provided would usually cater for students with average level of proficiency as it was made for the use of all the students in the same form. 
Therefore, some of the teachers would not use the software provided as they are not suitable for their students. Besides that, teachers mentioned that students could learn effectively with or without the ICT tools as long as they had the positive attitude of learning. Although the opinion was acceptable, it only applied to students who were diligent and had the motivation in learning. The students who were slightly slow in learning they would feel uninterested and tired of learning if the teachers were to use the same teaching method for every lesson. Their interest in learning would be decreasing day by day and that was why ICT integration was important in attracting their attention in learning.

\section{Perceptions on the Use of ICT in the Classroom}

For the questions on 'positive attitude towards ICT usage in teaching', the findings showed that most of the respondents had a positive view of ICT for English Language teaching. Table 3.0 shows the percentages (highlighted) of the highest frequency of each of the item. $83.3 \%$ of the respondents agreed that they would like to be able to ask questions to experts and relevant people, no matter where they were. Besides that, $83.3 \%$ of the respondents agreed and $16.7 \%$ of the respondents strongly agreed that they would like to discuss topics with people from different backgrounds. $72.2 \%$ of the respondents agreed and $5.6 \%$ of the respondents strongly agreed that ICT could improve students' learning.

$38.9 \%$ of the respondents agreed that they would like to teach using a computer, even if it was complicated. $88.9 \%$ of the respondents agreed and $5.6 \%$ of the respondents would like to share information and ideas with people who had similar interests. While $83.3 \%$ of the respondents agreed and $5.6 \%$ of the respondents strongly agreed on audio and video materials could improve their students" learning. $72.2 \%$ of the respondents agreed and $11.1 \%$ of the respondents strongly agreed that ICT had allowed for effective sharing of experiences. Lastly, 77.8\% of the respondents agreed that the use of ICT had made their lessons more fun for their students.

Table 3.0 Teachers' perceptions on the use of ICT in the classroom

\begin{tabular}{|l|l|l|l|l|l|l|}
\hline No & Criteria & $\begin{array}{l}\text { Strongly } \\
\text { Agree }\end{array}$ & Agree & $\begin{array}{l}\text { Not } \\
\text { Sure }\end{array}$ & Disagree & $\begin{array}{l}\text { Strongly } \\
\text { Disagree }\end{array}$ \\
\hline 1. & $\begin{array}{l}\text { I want to be able } \\
\text { to ask questions } \\
\text { to experts and } \\
\text { relevant people, } \\
\text { no matter where } \\
\text { they are general, }\end{array}$ & $11.1 \%$ & $77.8 \%$ & $5.6 \%$ & $5.6 \%$ & $0.0 \%$ \\
\hline 2. & $\begin{array}{l}\text { In } \\
\text { teaching with ICT } \\
\text { is very time- } \\
\text { consuming }\end{array}$ & $\begin{array}{l}\text { I think that face } \\
\text { to face contact }\end{array}$ & $16.7 \%$ & $61.1 \%$ & $16.7 \%$ & $5.6 \%$ \\
\hline
\end{tabular}




\begin{tabular}{|c|c|c|c|c|c|c|}
\hline No & Criteria & $\begin{array}{l}\text { Strongly } \\
\text { Agree }\end{array}$ & Agree & $\begin{array}{l}\text { Not } \\
\text { Sure }\end{array}$ & Disagree & $\begin{array}{l}\text { Strongly } \\
\text { Disagree }\end{array}$ \\
\hline & $\begin{array}{l}\text { with teacher is } \\
\text { more effective }\end{array}$ & & & & & \\
\hline 4. & $\begin{array}{l}\text { It is good to } \\
\text { discuss topics } \\
\text { with people from } \\
\text { different } \\
\text { background }\end{array}$ & $16.7 \%$ & $83.3 \%$ & $0.0 \%$ & $0.0 \%$ & $0.0 \%$ \\
\hline$* 5$. & $\begin{array}{l}\text { I prefer reading } \\
\text { from a printed } \\
\text { text }\end{array}$ & $5.6 \%$ & $55.6 \%$ & $27.8 \%$ & $11.1 \%$ & $0.0 \%$ \\
\hline 6. & $\begin{array}{l}\text { I think that ICT } \\
\text { can improve } \\
\text { students' learning }\end{array}$ & $5.6 \%$ & $72.2 \%$ & $16.7 \%$ & $0.0 \%$ & $0.0 \%$ \\
\hline$* 7$. & $\begin{array}{l}\text { Quality } \\
\text { information is } \\
\text { hard to find on } \\
\text { the web (www) }\end{array}$ & $0.0 \%$ & $16.7 \%$ & $44.4 \%$ & $33.3 \%$ & $5.6 \%$ \\
\hline 8. & $\begin{array}{l}\text { I would like to } \\
\text { teach with a } \\
\text { computer, even if } \\
\text { it is complicated }\end{array}$ & $0.0 \%$ & $38.9 \%$ & $27.8 \%$ & $33.3 \%$ & $0.0 \%$ \\
\hline$* 9$. & $\begin{array}{l}\text { If a task becomes } \\
\text { too difficult for } \\
\text { me to complete, I } \\
\text { am likely to drop } \\
\text { it }\end{array}$ & $0.0 \%$ & $33.3 \%$ & $38.9 \%$ & $27.8 \%$ & $0.0 \%$ \\
\hline 10. & $\begin{array}{l}\text { I would like to } \\
\text { share information } \\
\text { and ideas with } \\
\text { people who have } \\
\text { similar interests }\end{array}$ & $5.6 \%$ & $88.9 \%$ & $5.6 \%$ & $0.0 \%$ & $0.0 \%$ \\
\hline 11. & $\begin{array}{l}\text { I think audio and } \\
\text { video materials } \\
\text { can improve my } \\
\text { students' learning }\end{array}$ & $5.6 \%$ & $83.3 \%$ & $11.1 \%$ & $0.0 \%$ & $0.0 \%$ \\
\hline 12. & $\begin{array}{l}\text { ICT allows for } \\
\text { effective sharing } \\
\text { of experiences }\end{array}$ & $11.1 \%$ & $72.2 \%$ & $5.6 \%$ & $11.1 \%$ & $0.0 \%$ \\
\hline$* 13$. & $\begin{array}{l}\text { I prefer to teach } \\
\text { with traditional } \\
\text { teaching methods }\end{array}$ & $0.0 \%$ & $27.8 \%$ & $33.3 \%$ & $38.9 \%$ & $0.0 \%$ \\
\hline$* 14$. & $\begin{array}{l}\text { If teaching with } \\
\text { computer turns }\end{array}$ & $0.0 \%$ & $44.4 \%$ & $27.8 \%$ & $27.8 \%$ & $0.0 \%$ \\
\hline
\end{tabular}




\begin{tabular}{|c|c|c|c|c|c|c|}
\hline No & Criteria & $\begin{array}{l}\text { Strongly } \\
\text { Agree }\end{array}$ & Agree & $\begin{array}{l}\text { Not } \\
\text { Sure }\end{array}$ & Disagree & $\begin{array}{l}\text { Strongly } \\
\text { Disagree }\end{array}$ \\
\hline & $\begin{array}{l}\text { out to be too } \\
\text { complex, I would } \\
\text { like to return to } \\
\text { traditional } \\
\text { teaching methods }\end{array}$ & & & & & \\
\hline 15. & $\begin{array}{l}\text { The use of ICT } \\
\text { makes my lessons } \\
\text { more fun for my } \\
\text { students }\end{array}$ & $11.1 \%$ & $77.8 \%$ & $11.1 \%$ & $0.0 \%$ & $0.0 \%$ \\
\hline$* 16$. & $\begin{array}{l}\text { Computer-based } \\
\text { teaching/learning } \\
\text { lacks in 'human' } \\
\text { interaction, since } \\
\text { there is no face to } \\
\text { face contact }\end{array}$ & $5.6 \%$ & $50.0 \%$ & $16.7 \%$ & $27.8 \%$ & $0.0 \%$ \\
\hline
\end{tabular}

As for the questions on 'positive attitude towards teaching with traditional method, $77.8 \%$ of the respondents agreed and $11.1 \%$ of the respondents strongly agreed that teaching with ICT was very time-consuming. $61.1 \%$ of the respondents agreed and $16.7 \%$ of the respondents strongly agreed that face to face contact with teacher was more effective. Besides that, $55.6 \%$ of the respondents preferred and $5.6 \%$ of the respondents strongly preferred reading from a printed text. Majority of the respondents $(44.4 \%)$ were not sure about the statement quality information that was hard to find on the web (www). Majority of them (38.9\%) were not sure if they would drop the task if it had become too difficult for them to complete, while $38.9 \%$ of the respondents disagreed to teach with traditional teaching methods while a larger number of respondents $(44.4 \%)$ agreed that if teaching with a computer turned out to be too complex, they would like to return to using traditional teaching methods. Lastly, half of the respondents (50.0\%) agreed that computer-based teaching and learning lacked human interaction, since there was no face to face contact.

In sum, the teachers had a positive view on the use of ICT in the classroom rather than teaching with traditional method. This was because when asked about the questions on "positive attitude towards ICT usage in teaching', they stated that the implementation of ICT could help to enhance their teaching as long as it is not too complicated and easily accessible for teachers and also students. They believed that the use of certain programmes and software would actually motivate the students compared to the current practice of teacher-centred classroom where the teacher would be the only source of information. This is because the students would need to find a way to look for information on the internet and surf for more knowledge on their own as what Lee (2000) explained said on the use of ICT in the classroom where the students would be the creators who would have to find their own way to the knowledge. 
Besides that, the teachers do acknowledge the usefulness of the ICT tools in the process of teaching and learning as mentioned by Warschauer and Healey (1998) and Ariew and Atwood (2002) in the use of Computer Assisted Language Learning (CALL) in drills and practices, tutorials, simulations, games, contextualised activities and tool programs which would make the learning process more appealing and attention-grabbing. Moreover, the teachers agree on the concept of sharing information through online application such as email, blogging, internet chit-chatting among teachers and also the students which could help in the process of learning. This is explained by Blood (2002), Mayes and Fowler (1999) and William and Jacobs (2004) that the practice of online sharing and interacting could provide a space for the students to express and share ideas with the public and at the same time teachers could keep track of the students' learning. Students would have a 'high levels of autonomy' which meant that they would be more independent and responsible for their own learning and there would be no limitation of information sharing as long as both sides had the internet connection and a suitable webpage for them to view and post the information. This would shorten the time for the information to spread within a targeted community making the process of sharing faster and effective.

The findings show that the perception of the use of ICT in teaching is positively related to the ICT literacy of the teachers as the survey showed that teachers with higher ICT literacy level would have more positive attitude towards the use of ICT in the classroom compared to the one with lower ICT literacy level. This means that in order to change the perceptions of the teachers towards ICT use in the classroom, the most important step is to develop their ICT literacy by providing them with the training or courses needed. This is because the teachers with higher literacy in ICT would know their role when they implement ICT in their teaching. The roles of the teacher would be different for a classroom which uses traditional teaching methods and a classroom which implements the use of the ICT. Roger and Quentin (2003) have listed some assumptions based on previous conventional classroom teaching and also some expectations of the teachers in order to carry out the practice of ICT in classroom. Besides that, Pennington (1996) and Salbiah (2008) have also listed down the roles of teachers for a language classroom that could act as a guide for teachers to recognise their responsibility as a language teacher.

\section{CONCLUSION}

This study investigated teachers' practices and perceptions in using ICT in English Language Teaching (ELT). It focused on the obstacles faced by English language teachers in using ICT in their lessons, some of the measures that could increase their use of ICT in the classroom and the perceptions of the teachers on teaching using ICT and without ICT in the classroom.

The major findings of the research on the obstacles faced by the English teachers in using ICT include the lack of ICT literacy among the teachers and the lack of time allocated for their teaching and learning process. The overall ICT literacy of the teachers can be said to be still limited and needs to be improved especially in the use of internet so that they could have more confidence in implementing ICT in their classroom without hesitation. Besides that, more time would be needed to implement ICT in the classroom as the teachers had to struggle to set up the tools such as the LCD, 
computers, and the software or programmes that they would be using. The schools should have take actions promoting and motivating the teachers to implement ICT in the classroom by having some motivational talks or providing the teachers with variety choices of software that could be used by the teachers in the classroom. When the teachers are motivated and determined enough, they will definitely be willing to sacrifice their time to look for the latest ICT-based materials to be used in the classroom and the problems of insufficient software too could be resolved at the same time. The findings has shown that the teachers are not provided with proper ICT training prior to this study and they are hoping that the school could provide them with more training on the use of internet such as (i) getting information and research about best practices for teaching, (ii) creating a website to share classroom activities, (iii) using internet to participate in discussions about teaching and learning, (iv) using electronic encyclopaedias and dictionaries, (v) sharing documents electronically with others and (vi) getting lesson plans and activities form electronic/internet sources.

On the teachers' perceptions towards teaching using ICT and without ICT in the classrooms concluded that the teachers had more positive attitude towards using ICT in the classrooms and they have the intention to implement ICT in their teaching. This shows that the teachers would opt for the use of ICT in the teaching but are restricted because of some of the obstacles. This study recommends that schools should provide more training and ICT courses to teachers according to their needs to improve the teachers' ICT literacy, as the main problems that seem to be restricting the teachers in using ICT in their teaching is the lack of ICT skills and also confidence in implementing ICT in the classroom.

It is worth noting that the findings of this study could be considered a pre-Covid 19 pandemic era scenario whereby teachers had the option of choosing not to integrate ICT due to the barriers and challenges they faced.Today however, with digital disruption and educational disruption, teachers and students are part of virtual classrooms. Questions arise as to how teachers and students, especially those in remote areas, were and are coping with virtual classrooms? With the lack of internet and computer facilities, lack of online teaching annd learning skills during the lockdown, have teachers upgraded their ICT skills as they have been forced to conduct virtual classes with very little warning and preparation? Are they more motivated now that they have been literally thrown into practising virtual classrooms? Our suggestion is that as we are now faced with living in the 'new normal' where virtual classrooms have become a reality, thus more research must be undertaken to assess teachers' current level of ICT skills following the Covid 19 pandemic to identify their needs, challenges and barriers. And based on this, it is up to the Ministry of Education to act accordingly.

\section{REFERENCES}

Ahmadi, M. R. 2018.The use of Technology in English Language Learning: A Literature Review. International Journal of Research in English Education. 3(2): 115 - 125.

Albirini, A. A. 2006. Teacher's Attitudes toward Information and Communication Technologies: The Case of Syrian EFL teachers. Journal of Computers and Education. 47: 373-398.

Amabile, T. and Hennessey, B. A. 1992. The Motivation for Creativity in Children. In A. K. 
Boggiano and T. S. Pittman (Eds.). Achievement and motivation: A Social Developmental Perspective (p. 54-76). New York: Cambridge University Press.

Azizah, J. 2006. The Usability of Malaysian Smart School Courseware: Users' Satisfaction,

Perception and Usage Aspect. Accessed 26 September 2010:

http://unesdoc.unesco.org/images/0012/001295/129538e.pdf.

Becker, H. J. 2000. Pedagogical Motivations for Student Computer use that Lead to Student Engagement. Educational Technology.

Bingimlas, K. A. 2009. Barriers to the Successful Integration of ICT in Teaching and Learning

Environments: A Review of the Literature. Accessed 30th June 2009: http://www.ejmste.com/v5n3/EURASIA_v5n3_Bingimlas.pdf

Blood, R. 2002. The Weblog Handbook: Practical Advice on Creating and Maintaining Your Blog. Cambridge, MA: Perseus.

Blurton, C. 1999. New Directions of ICT-Use in Education, World Communication and Information Report. UNESCO.

Candlin, C. 1987. Toward Task-based Learning. In C. Candlin and D. Murphy (Eds.). Language Learning Tasks. Englewood Cliffs, N.J: Prentice Hall.

Chan, F. M. 2002. ICT in Malaysian Schools: Policy and Strategies. Accessed 27 September 2010: http://unpanl.un.org/intradoc/groups/p

HYPERLINK

"http://unpanl.un.org/intradoc/groups/public/documents/apcity/unpan011288.pdf"

HYPERLINK

"http://unpanl.un.org/intradoc/groups/public/documents/apcity/unpan011288.pdf"ublic/docu ments/apcity/unpan011288.pdf.

Chia, H. S., Lau, B. T. 2008. Teachers' Perceptions of the Use of ICT as an Instructional Tool in Mathematics and Science. Accessed 29 September 2010: http://ictl.intimal.edu.my/ictl2007/proceeding/Full_Paper/1A 03Paper\%2069\%20(Malaysia).pdf.

Cuckle, P., Clarke, S., and Jenkins, I. 2000. Students' Information and Communications Technology Skills and Their Use During Teacher Training. Journal of Information Technology for Teacher Education. 9(1): 9-22.

Simin, G. and Ibrahim Mohammed Sani, 2015. Effectiveness of ICT Integration in Malaysian Schools: A Quantitative Analysis. International Research Journal for Quality in Education. 2(8): 1-12.

Hanapiah, M. F. 2002. English Language and the Language of Development: A Malaysia $\begin{array}{llll}\text { Perspective. } & \text { Accessed } & 26 & \text { September }\end{array}$ http://apps.emoe.gov.my/ipba/rdipba/cdl/article113.pdf.

Hafifah, G. N. 2020. Teachers Perspective of ICT Integration in English Language: A Review of Literature. Journal English Educators Society. 5(1): 9-15.

Ibrahim, A. M. I. 2010. Information and Communication Technologies in ELT. Accessed 30th June 2009: http://www.academypublisher.com/ojs.

Ismail, S. 2008. ICT and School Linkages. Accessed 26 September 2010: http://www.scribd.com/doc/11003700/MALAYSIA-ICT-and-School- Linkages

Jegede, P. O., Odusola, O. D., and Ilori, M. O. 2007. Relationships between ICT Competence and 
Attitude among Nigerian Tertiary Institution Lecturers. Educational Research and Review. 2(7): $172-175$.

Lee, K. W. 2000. English Teachers' Barriers to the Use of Computer Assisted Language Learning, The Internet TESL Journal. Accessed 26 September 2010: http://www.4english.cn/englishstudy/xz/thesis/barriers

Mahdum, Hadriana, \& Safriyanti, M. 2019. Exploring Teacher Perceptions and Motivations to ICT Use in Learning Activities in Indonesia. Journal of Information Technology Education: Research. 18: 293-317. https://doi.org/10.28945/4366.

Malaysia Education Blueprint 2013-2025. 2012. Preliminary report: Executive summary, Retrieved from http://www4.unescobkk.org/nespap/sites/default/files/Preliminary-Blueprint-ExecSumma ry-Eng_0.pdf.

Masood, M. and Ngah, N. A. 2003. The Status of Various Technology Used for Teaching and Learning at the Primary Schools. Proceedings from the Malaysian Educational Technology Assocation (META) 16th Convention, Hotel City Bayview, Melaka, 13-16 June, 2003.

Marcheggiano, G. 2000. A Case Study of ICT and School Improvement at G Rodari Primary School Udine, Italy. Accessed 30th June 2009: http://www.oec HYPERLINK "http://www.oecd.org/dataoecd/39/33/2739498.pdf" HYPERLINK

"http://www.oecd.org/dataoecd/39/33/2739498.pdf"d.org/dataoecd/39/33/2739498.pdf

Mayes, T. 2006. Theoretical Perspectives on Interactivity in e-learning. In C. Juwah (Ed.). Interactions in Online Education: Implications for Theory and Practice. New York: Routledge.

O'Donnell, A. M., Reeve, J., and Smith, J. K. 2007. Educational Psychology. Reflection for Action. USA: Wiley.

Padurean, A. and Margan, M. 2009. Foreign Language Teaching Via ICT. Accessed 30th June 2009: http://www.ris.uvt.ro/wpcontent/ HYPERLINK "http://www.ris.uvt.ro/wpcontent/uploads/2010/01/apadurean.pdf"uploads/2010/01/apadurean. pdf

Pennington, M. C. 1996. The Power of the Computer in Language Education. In Pennington, M. C. (Ed). The Power of CALL. Houston: Athelstan. (p.7)

Peterson, M. 1997. Language Teaching and Networking. System. 25(1): 29-37.

Preston, C., Cox, M., and Cox, K. 2000. Teachers as Innovators in Learning: What Motivates Teachers to Use ICT, Miranda Net. Accessed 18 September 2010: http://www.mirandanet.ac.uk/pubs/tes_art.htm.

Ariew, R. and Atwood, J. 2002. Interactive Language Teaching. Cambridge University Press.

Roger, L., and Quentin, W. 2003. How to Plan and Manage an E-learning Programme. US: Gower Publishing Company.

Salbiah, I. 2008. ICT and School Linkage. Accessed 23 October 2010:http://www.scribd.com/doc/11003700/MALAYSIA-ICT-and-School- Linkages.

Sa'ari, J. R., Wong, S. L., Roslan, S. 2005. 'In-service Teachera' Views toward Technology and Teaching and their Perceived Competency toward Information Technology. Journal of Technology. 43€: 1-14 
Shetzer, H., and Warschauer, M. 2000. An Electronic Literacy Approach to Network-based Language Teaching. (p. 171-185). New York: Cambridge University Press.

Singhal,V. 2010. Using Devises and Technology to Improve Language Skills. Accessed 20 September 2009: http://www.brighthub.com/education/languages/articles/735 HYPERLINK "http://www.brighthub.com/education/languages/articles/73591.aspx\#ixzz10Z" HYPERLINK "http://www.brighthub.com/education/languages/articles/73591.aspx\#ixzz10Z"91.aspx\#ixzz10 $\mathrm{Z}$

Sivapalan, S. and Ahmad, W. F. W. 2010. A Web-Based Multimedia Approach to Literature in Malaysian Secondary Schools: Learners' Preference. Accessed $30^{\text {th }}$ June 2009: http://www.eurojournals.com/ejss_12_3_01.pdf.

Tapscott, D. 1997. Growing up Digital:The Rise of the Net Generation. New York: McGraw-Hill.

Tapscott, D. 1997. The Digital Media and the Reinvention of Government. Canadian Public Administration.

Warschauer, M. and Healey D. 1998. Computers and Language Learning: An Overview. Language Teaching. 31: 57-71.

Williams, J. B. and Jacobs, J. 2004. Exploring the Use of Blogs as Learning Spaces in the Higher Education Sector. Australasian Journal of Educational Technology. 20(2): 232-247. Accessed 26 September 2010: http://www.ascilite.org.au/ajet/ajet20/williams.html.

White, J. 2009. The Use of Facebook to Improve Motivation and Academic Writing. Accessed 30th June 2009: http://wirelessready.nucba.ac.jp/white2009.pdf.

Ya'acob, A., Nor, N. F. M. , and Azman, H. 2005. Implementation of the Malaysian Smart School: An Investigation of Teaching-Learning Practices and Teacher- Student Readiness. Internet Journal of e-Language Learning and Teaching. 2(2). Accessed 30th June 2009: http://myais.fsktm.um.edu.my/10414/1/AzizahYaacob.pdf.

Yin, R. 1984. Case Study Research: Design and Methods. Beverly Hills, CA: Sage Publishing. 